\title{
Organizational diagnoses based on green management model: A case study of an Iranian pipe and equipment company in steel industry
}

\author{
Jalal Haghighat Monfared and Mehrnoush Dowlat Madani*
}

Department of Management, Islamic Azad University, Central Tehran branch, Tehran, Iran

\begin{tabular}{|c|c|}
\hline A R T I C L E I N F O & A B S T R A T T \\
\hline $\begin{array}{l}\text { Article history: } \\
\text { Received September 1, } 2011 \\
\text { Received in Revised form } \\
\text { November, 10, } 2011 \\
\text { Accepted } 10 \text { November } 2011 \\
\text { Available online } \\
14 \text { November } 2011 \\
\text { Keywords: } \\
\text { Green Management } \\
\text { Enablers } \\
\text { Sustainable success } \\
\text { Diagnoses } \\
\text { Environmental results }\end{array}$ & $\begin{array}{l}\text { Green management plays an important role having better environment friendly industry and it is } \\
\text { one of the prominent methods for reducing future issues surrounding our planet. The present } \\
\text { study presents an empirical study of the implementation of green management for a real-world } \\
\text { case study of steel industry. The study designs a questionnaire and distributes it among some } \\
\text { experts from a steel industry. One of the main objectives of the survey is to investigate whether } \\
\text { the firm is in good conditions in terms of green management perspective and the preliminary } \\
\text { results of our survey indicate that the company received } 344.6 \text { points out } 1000 \text { points, which } \\
\text { means the present conditions of the firm is quite unfavorable. There are many reasons } \\
\text { describing the present conditions of the firm such as the lack of an integrated responsibility, } \\
\text { weak management support and involvement, shortage of financial support, etc. The study also } \\
\text { provides some guidelines for having better green management outcomes, which are setting } \\
\text { better accounting procedures for evaluating the cost/benefit of projects and priding sufficient } \\
\text { financial support for projects. }\end{array}$ \\
\hline
\end{tabular}

\section{Introduction}

Green management approach is a new managerial strategy to develop the organization enablers including leadership, policy and strategy, corporate partners, corporate resources and processing for sustainable business success in terms of financial, social and environmental results. Green management helps naturalize behaviors and the functions associated with learning and creativity and innovation to become industrial competitiveness.

During recent years, increasing environmental pollution by various industries and consequently the incidence of global protests, green management tries to keep a stable relationship between the enablers and the success of an organization. Green management association was formed with the aim of improving and integrating all of the organizational criteria and tries to assess the five mentioned criteria and consequently enhance the environmental, social and economic results.

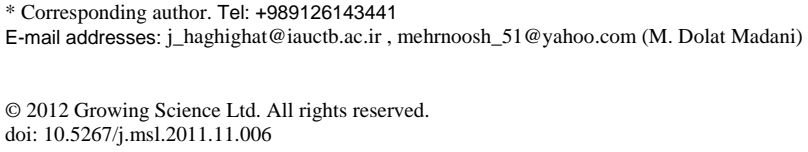


The "Green Management Award" in the UN-affiliated organization called the "Energy Globe" has been registered and has a universal validity.

During the past few decades, there have been tremendous efforts on how to reach sustainable environment. Some of the works are dedicated to Natural Step (Bradbury \& Clair 1999), sustainable development (Bansal \& Roth, 2000), private sector and non-governmental organization (NGO) partnerships in the sustainability domain (Rondinelli \& London 2003) global environmental programs (Christmann \& Taylor 2002), and engaging so-called 'fringe' stakeholders to construct sustainable business models (Hart \& Sharma 2004).

Robèrt (2000) explained tools and concepts for sustainable development and addressed how they are associated with a general framework for sustainable development. The framework is based on some principles, which describes how a system is constituted in terms of ecological and social and their roles for a favorable outcome for the system (sustainability), as well as the roles for the process to reach the sustainable development. The roles for sustainability define the advantages towards problem sources. A program of activities is built by back casting from defined outcomes to the current problems. This is based on "metrics" or various concepts for measuring and monitoring the activities. An environmental management system (EMS), like ISO 14001 is an administrative tool, which should systematically align a firm's specific outcomes, activities and metrics with a general framework for sustainability. From a strategic point of view, metrics should measure alignment of activities with the roles contained in a framework for sustainability.

Hezri and Hasan (2004) presented a management framework for sustainable development indicators in the State of Selangor, Malaysia and they carefully examined the ideals of participatory decisionmaking, the principles of the rational model and decision-making processes within a state government.

MacDonald (2005) explained that important of the ISO 14001 environmental management system standard as an administrative framework in the field of corporate responses to sustainability. He argued that ISO 14001 in itself neither speaks of strategic planning for sustainability, nor of upstream solutions of problems at their source. In addition, he belived there was confusion with respect to where ISO 14001 matches to a complex array of tools for sustainable development. He proposed the integration of a "backcasting" technique, which embodies a five-level approach for planning in complex systems, with the ISO 14001 planning process requirements.

Midilli et al. (2006) presented some green energy strategies for sustainable development by investigating seven green energy strategies to choose the sectoral, technological, and application influence ratios. They extracted a new parameter as the green energy impact ratio, where the green energy-based sustainability ratio was achieved based on the green energy impact ratio, and the green energy utilization ratio, which was estimated using actual energy data taken from literature. They considered cases to verify their observations, reported that the sectoral impact ratio was more important, and should be kept constant in a green energy policy implementation. In addition, they reported that the green energy-based sustainability ratio could increase with an increase of technological, sectoral, and application influence ratios. In other words, all negative influences on the industrial, technological, sectoral and social developments partially and/or completely decrease. Therefore, the sustainable energy strategies play important role to the economies of the countries. Therefore, governments and other authorities should persuade the investment in green energy supply and progress.

Hall et al. (2010) explained the emerging research associated with sustainable development and entrepreneurship. Entrepreneurship is one of the major efforts for sustainable products and processes, and new ventures play important role for many social and environmental problems. Hall overviewed of sustainable development and the role of entrepreneurship and outline recent contributions exploring this role. Seuring and Müller (2008) presented a comprehensive review on conceptual 
framework for sustainable supply chain management. Byggeth et al. (2007) presented a method for sustainable product development based on a modular system of guiding questions. The method implemented backcasting from basic principles for sustainability and included a modular system of guiding questions derived by studying the principles and the product life cycle.

Environmental management system (EMS) is one of the vital techniques for having sustainable economy. Lam et al. (2011) defined green characteristics, identified the reasons for implementing green specifications, and presented the environmental factors, which were not addressed by solely adopting EMS. They also presented the outcomes of a recent survey of practitioners concerning their ideas about green specifications and possible influences arising from their adoption.

The study is diagnoses based on Green Management Award model for Identification of improvement plans in the case study of a company named the Sadid Pipe and Equipment Company in steel industry, which was conducted by the researcher from 2010 to 2011. The study is divided in to two parts of quality and quantity, in quantity part, while reviewing the current models used in diagnoses, enumerating the reasons necessary to implement green management in organizations and with using an appropriate checklist we verify the results. In the next phase by using quality analysis, the group of experts on corporate executives and some experts in the fields are formed and the results of the quantitative sector in research with an organizational diagnoses approach is investigated.

The first, evidence from the existence of the diagnoses in enablers and consequently in the results of three in sustainable success area are identified based on the company's main problem. Next, we present the most common causes of each complication, solutions in order to address weaknesses and overcoming the diagnoses of company proposed to improve the environmental, social and economic results of company.

This paper is organized as follows. We first present the details of our survey in section 2. Section 3 explains details of our survey and finally concluding remarks are given in the last to summarize the contribution of the paper.

\section{Proposed study}

In this study, we attempt to find appropriate responses for three main questions. The first question is associated with organizational diagnostic of the proposed case study from green management perspective and the second question looks for the roots of the problems. We also investigate to find appropriate plans for emerging towards green management. The primary assumption is that the proposed case study of this research work is not in good conditions in terms of green management perspectives. Fig. 1 shows different attributes and their components.

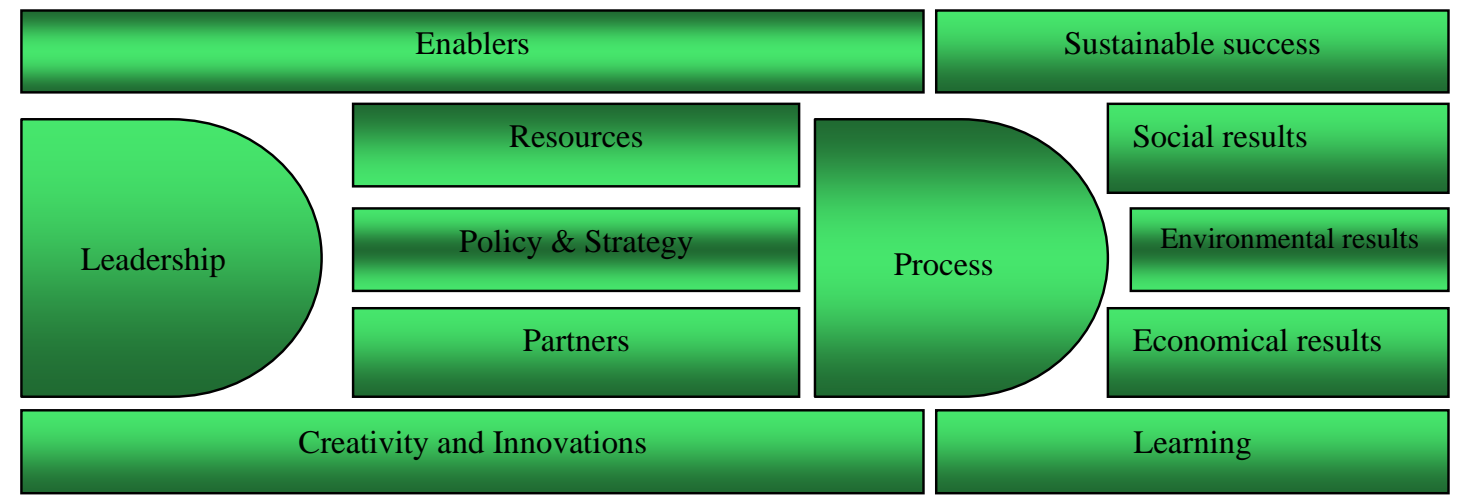

Fig. 1. The components of green management 
The study was performed on steel industry unit called SADID Group in Iran and has become one of the most active units in steel industry with 200 billion Rials capital. The company is presently considered as a holding unit with various subunits and it is active in many industries such as sugar, oil \& gas, pipelines, etc. During the last few years, the company was commissioned to construct seven major industrial projects based on EPC for sugar processing plants with annual 100,000 tons capacity each per year.

The sampling of our survey includes 11 managers, 12 top manager, 50 engineers totaling 73 people. There were some necessary requirements for selecting the people in our interview. They must maintain a minimum bachelor degree, must work as full time employee, and actually interested in our survey. The survey was based on international prize, which is a valid and reliable form and the survey was performed using authorized experts. After a careful investigation we realized that we can use 60 percent $\left(H_{0}: \mu \geq 60\right)$ as a reliable number for our investigation. Table 1 summarizes the results of our survey for all eight criteria.

\section{Table 1}

The summary of our survey for eight criteria

\begin{tabular}{llll}
\hline Criteria & Point & Weight & Sum \\
\hline Leadership & 39.855 & 1.2 & 47.83 \\
Strategy & 14.17 & 1.3 & 18.42 \\
Organizational resources & 30.35 & 1.5 & 45.53 \\
Organizational partnership & 35.83 & 2 & 71.66 \\
Environmental benefits & 68.05 & 1.5 & 102.75 \\
Social benefits & 15.94 & 0.6 & 9.56 \\
Economical benefits & 21.69 & 0.9 & 19.52 \\
\hline Total & & & 344.60 \\
\hline
\end{tabular}

\section{The results}

In this section, we present details of our study to examine three main hypotheses as well as some other detailed hypothesis. Table 2 shows details of our survey for our proposed study.

\subsection{The results for the first hypothesis}

\section{Table 3}

The results of the first main hypotheses and its sub-hypothesis

\begin{tabular}{|c|c|c|}
\hline The hypothesis & Point & Results \\
\hline $\begin{array}{l}\text { Main hypothesis: The firm is not in good conditions in terms of green } \\
\text { management perspective }\end{array}$ & 344.6 & $H_{0}$ is rejected \\
\hline Sub hypothesis: The firm is not in good condition in terms of leadership & 39.86 & $H_{0}$ is rejected \\
\hline Sub hypothesis: The firm is not in good condition in terms of strategy & 14.17 & $H_{0}$ is rejected \\
\hline $\begin{array}{l}\text { Sub hypothesis: The firm is not in good condition in terms of human } \\
\text { resources }\end{array}$ & 30.35 & $H_{0}$ is rejected \\
\hline $\begin{array}{l}\text { Sub hypothesis: The firm is not in good condition in terms of having reliable } \\
\text { partners }\end{array}$ & 29.33 & $H_{0}$ is rejected \\
\hline Sub hypothesis: The firm is not in good condition in terms of processes & 35.83 & $H_{0}$ is rejected \\
\hline $\begin{array}{l}\text { Sub hypothesis: The firm is not in good condition in terms of environmental } \\
\text { affairs }\end{array}$ & 68.05 & $H_{1}$ is rejected \\
\hline Sub hypothesis: The firm is not in good condition in terms of social affairs & 15.94 & $H_{0}$ is rejected \\
\hline $\begin{array}{l}\text { Sub hypothesis: The firm is not in good condition in terms of economical } \\
\text { affairs }\end{array}$ & 21.69 & $H_{0}$ is rejected \\
\hline
\end{tabular}


As we can observe from the results of Table 3, the main hypothesis, which is having $H_{0}: \mu \geq 60$, is rejected and we can conclude that the firm in overall is not in good condition in terms green management. There are four groups of green management awards, which are green commitment for firms hold between 150-300 points, green appreciation for businesses hold between 300-450 points, green management for companies maintain between 450-600 points and green organization for organizations with 600-1000 points. There are also three levels associated with each group.

The proposed case study has received 344.6 point out of 1000 points dedicated to an ideal unit during the fiscal years of 2010 and 2011 based on green management perspectives. According the ranking strategy explained earlier in green management technique, the firm is considered as level one green appreciation. Table 4 shows details of our action plans.

\section{Table 4}

Action plans

\begin{tabular}{|c|c|c|}
\hline Feature & Characterization & Evaluation \\
\hline $\begin{array}{l}\text { The positive } \\
\text { applicable } \\
\text { results }\end{array}$ & Performance and trends & $\begin{array}{l}\text { Trend was at least } 1 / 4 \text { for a three-year period. } \\
\text { Key solution strategies were good only for } 1 / 4^{\text {th }} \text { of the } \\
\text { decisions. } \\
\text { Benchmarks were good only for } 1 / 4^{\text {th }} \text { of the decisions. } \\
\text { Sustainable empowering items were good only for } 1 / 4^{\text {th }} \text { of } \\
\text { the decisions. } \\
\text { The results lead to sustainable outcomes only for about } \\
1 / 4^{\text {th }} \text { of the decisions. } \\
\text { The necessary data were given for } 1 / 4^{\text {th }} \text { of the decision } \\
\text { making process. }\end{array}$ \\
\hline Approaches & Integ & There are few evidences of crystal clear performance. \\
\hline Execution & Actions wi & $\begin{array}{l}\text { There are few evidences for taking appropriate actions for } \\
\text { at least } 1 / 4^{\text {th }} \text { of the decision. }\end{array}$ \\
\hline Evaluation & $\begin{array}{l}\text { Evaluation of the } \\
\text { improvement }\end{array}$ & $\begin{array}{l}\text { Performance measurement was not performed properly. } \\
\text { Learning has not been used properly. } \\
\text { Planning, ranking and execution have not been performed } \\
\text { properly. }\end{array}$ \\
\hline
\end{tabular}

\subsection{Green management actions}

Next, we have to take the necessary actions for having better green management of the system. To achieve this goal we need to consider green management for all components of the organization. It is necessary to have green management accounting system to evaluate the actual benefits of green management actions. Executing green management must be performed in national level to increase the benefit for the country.

\subsection{System diagnostics}

In this section, we present details of our investigation on the possible reasons for having failure green management system.

\subsubsection{Enablers}

The following are some of the most important factors influencing green management failure.

- The lack of an integrated responsibility,

- Weak management involvement, 
- The lack of a good support on behalf of top management team,

- The lack of a good promotion plan for implementation of green management,

- The lack of direct management for implementation of green management,

- The lack of complete implementation because of shortage of financial support,

- The lack of good channels among different components of organization,

- The weak relationship between management team and third party who benefit of the decisions,

- An inactive agents for assessing important factors influencing organizations,

- The lack of a good mission and future plan,

- The lack of a good training feedback,

- The lack of good experimental equipments and research facilities.

\subsubsection{The results division}

The following also summarizes some of barriers for the implementation of the green management system.

- The lack of a comprehensive accounting system to determine the impact of green management implementation,

- The lack of an independent agent for having environmental activities inside and outside the organization,

- The lack of a good financial support,

- The lack of sufficient attention to social outcomes of the implementation of environmental decisions.

\subsection{Suggestions}

In this section, we investigate on how we can improve green management through different efforts.

\subsubsection{Suggestion based on the first hypothesis}

The most important factors influencing the success of any green management efforts are to use integrated strategies. When there are comprehensive efforts among all components of a firm, we may be able to see better results in terms of economical, social and environmental aspects.

\subsubsection{Suggestion based on the second hypothesis}

There must be some efforts to determine and prioritize the beneficiaries of environmental actions so that all decisions are implemented, more effectively.

\subsubsection{Suggestion based on the third hypothesis}

It is obvious the any action for improvement of the system would need financial support and we need an encouraging promotion plan to have better cooperation among team members. Any effort in national level could create more motivation among members of case study and this would add more value for country.

\subsubsection{Suggestion based on the fourth hypothesis}

All necessary standards and requirements for better achieving green management are set and they are prioritized using different scientific decision-making techniques. 


\subsubsection{Suggestion based on the fifth hypothesis}

Prior the implementation of any green management effort, there must be some good training among the workers to make sure that the project is implemented, properly. A good implementation of supply chain management is also necessary and we must have enough awareness among members of team for the positive outcomes of the green management efforts.

\subsubsection{Suggestion based on the sixth hypothesis}

Any action must be proportion to company's abilities in terms of human resources, financial and organizational objectives. There must be a good effort for media awareness about the outcome of any green management project implementation.

\subsubsection{Suggestion based on the seventh hypothesis}

There is no doubt that creativity and innovation are the basis of any improvement in organizations.

Therefore, any green management effort must come through employments' insight and the media must be aware of the possible consequences of the implementation of projects.

\subsubsection{Suggestion based on the eight hypothesis}

All decisions must be made based on organizational financial objectives, which includes market, asset related issues. The performance of the organizations must be measured in terms of different cost items such as reduction in maintenance cost, increase in profitability, etc.

\section{Conclusion}

In this paper, we have presented an empirical study of the implementation of green management for a real-world case study of steel industry. The study was performed using a questionnaire, which was distributed among company's employees. One of the main objectives of the survey was to examine whether the firm was in good conditions in terms of green management perspective and the results of our survey indicated that the company received 344.6 points out 1000 points, which means the present conditions of the firm were undesirable. There were many reasons describing the present conditions of the firm such as the lack of an integrated responsibility, weak management support and involvement, shortage of financial support, etc. The study also provided some guidelines for having better green management outcomes, which are setting better accounting procedures for evaluating the cost/benefit of projects and priding sufficient financial support for projects.

\section{Acknowledgment}

The authors would like to put on record their appreciation for the two anonymous referees and the Editor for their valuable suggestions, which has significantly improved the quality of the paper.

\section{References}

Bradbury, H., \& Clair, J.A. (1999). Promoting sustainable organizations with Sweden's natural step. Academy of Management Executive, 13(4), 63-74.

Bansal, P., \& Roth, K. (2000). Why Companies Go Green: A Model of Ecological Responsiveness. Academy of Management Journal, 43(4), 717-48.

Byggeth, S., Broman, G., \& Robèrt, K.H. (2007).A method for sustainable product development based on a modular system of guiding questions. Journal of Cleaner Production, 15(1), 1-11.

Christmann, P., \& Taylor, G. (2002). Globalization and the environment: Strategies for international voluntary environmental interactions. Academy of Management Executive, 16(3), 121-135. 
Hall, J.K., Daneke, G.A., \& Lenox, M.J. (2010).Sustainable development and entrepreneurship: Past contributions and future directions. Journal of Business Venturing, 25(5), 439-448.

Hart, S.L., \& Sharma, S. (2004). Engaging Fringe Stakeholders for Competitive Imagination. Academy of Management Executive, February, 7-18.

Hezri, A.A., \& Hasan, M.N. (2004). Management framework for sustainable development indicators in the State of Selangor, Malaysia. Ecological Indicators, 4(4), 287-304.

Lam, P.T.I., Chan, E.H.W., Chau, C.K., Poon, C.S., \& Chun, K.P. (2011). Environmental management system vs green specifications: How do they complement each other in the construction industry?. Journal of Environmental Management, 92(3), 788-795.

Midilli, A., Dincer, I., \& Ay, M. (2006). Green energy strategies for sustainable development. Energy Policy,34(18), 3623-3633.

MacDonald, J.P. (2005). Strategic sustainable development using the ISO 14001 Standard. Journal of Cleaner Production, 13(6), 631-643.

Robèrt, K.H. (2000). Tools and concepts for sustainable development, how do they relate to a general framework for sustainable development, and to each other?. Journal of Cleaner Production, 8(3), 243-254.

Rondinelli, D.A. \& London, T. (2003). How Corporations and Environmental Groups Co-operate Assessing Cross-sector Alliances and Collaborations. Academy of Management Executive, 17(1), 61-75.

Seuring, S., \& Müller, M. (2008). From a literature review to a conceptual framework for sustainable supply chain management. Journal of Cleaner Production, 16(15), 1699-1710. 